\title{
Carboniferous bentonites of 10th Khutor deposit (Russia): geology, mineralogy, genesis and properties.
}

\author{
Petr Belousov $^{1 *}$, Nikita Chupalenkov ${ }^{2}$, George Christidis ${ }^{3}$, Sergey Zakusin ${ }^{1,4}$, Olga Dorzhieva ${ }^{1}$, \\ Ivan Morozov', Mikhail Chernov, ${ }^{4}$, Victoria Krupskaya ${ }^{1,4}$ \\ ${ }^{1}$ Institute of Geology of Ore Deposits, Petrography, Mineralogy and Geochemistry, Russian Academy of \\ Science (IGEM RAS), Staromonetny per. 35, Moscow 119017, Russian Federation; \\ zakusinsergey@gmail.com (S.Z.), dorzhievaov@gmail.com (O.D.), krupskaya@ruclay.com (V.K.) \\ ${ }^{2}$ Federal State Budgetary Institution “All-Russian Scientific-research Institute of Mineral Resources named \\ after N.M.Fedorovsky, Staromonetny per. 31, Moscow 119017, Russian Federation; \\ chupalenkovnm@gmail.com (N.Ch) \\ ${ }^{3}$ Technical University of Crete, 73133 Chania, Crete, Greece; chupalenkovnm@gmail.com (G. Ch.) \\ ${ }^{4}$ Lomonosov Moscow State University, Leninskie Gory 1, Moscow 119991, Russian Federation; \\ miha.chernov@yandex.ru (M. Ch.) \\ * Correspondence: pitbl@mail.ru; Tel.: +7-926-1873947
}

Received: date; Accepted: date; Published: date

Abstract: 10th Khutor deposit is located in the Republic of Khakassia and confined to the coalbearing formation of Carboniferous age within the development of continental tuff-sandyargillaceous sediments. In terms of mineral composition, bentonites are mainly composed of Al-rich montmorillonite. The content of montmorillonite reaches a maximum of $70-75 \%$, with an average content of 55 to $70 \%$. It is one of the main sources of bentonite for the metallurgical and foundry industries in Russia. One of the distinctive features of bentonites from the 10th Khutor deposit is that despite the age of the deposit, about 350 million years, and the presence of an initial phase of metamorphism, as evidenced by the formation of hard coal, these bentonites retained the ability to swell and have high thermal stability. The formation of bentonites is associated with the decomposition of volcanic ash of rhyodacite and dacite composition in zones of shallow seawater bays and lagoons. The properties of bentonite were influenced by the initial stage of metamorphism.

The main purpose of this work was to establish the conditions for the formation of this deposit, as well as to study the features of the mineral composition and physicochemical properties of these raw materials. In addition to fundamental issues, the aim of the work was applied research on the properties and quality of bentonites.

Keywords: bentonite, montmorillonite, genesis, volcano-sedimentary rocks, diagenetic alteration, volcanic glass.

\section{Introduction}

The 10th Khutor deposit is located in Siberia, $8 \mathrm{~km}$ southwest of the city of Chernogorsk (Republic of Khakassia, Russia) and is the main source of bentonite in Russia, with an annual production of about 300 thousand tons of bentonite products. One of the distinctive features of bentonites from the 10th Khutor deposit is its high thermal stability, due to the structure of montmorillonite. It should also be noted that despite the age of the deposit, about 350 million years, 
and the presence of an initial phase of metamorphism, as evidenced by the formation of hard coal, these bentonites retained the ability to swell.

Despite the detailed exploration of the 10th Khutor deposit in previous periods, studies of the genesis and structural features of bentonites have not yet been carried out. The main purpose of this work was to establish the conditions for the formation of this deposit, as well as to study the features of the mineral composition and physicochemical properties of these raw materials. In addition to fundamental issues, the aim of the work was applied research on the properties and quality of bentonites.

\section{Materials and Methods}

The work is based on field works at the 10th Khutor deposit in 2014 and 2019, during which the authors took the samples from productive layers of bentonite. For comparison and detailed study of montmorillonite structure, an industrial sample from the 6th productive layer (IB-6) with a relatively high content of montmorillonite $(72 \%)$ was added to the studied collection. Also, to study the structural features of montmorillonite, a fine fraction $<1 \mu \mathrm{m}$ was separated from a $3 \%$ aqueous suspension using an OS-6MTs laboratory centrifuge (Dastan, Kyrgyzstan). The centrifugation conditions: $9.5 \mathrm{~min}$ at $1200 \mathrm{rpm}$.

X-ray diffraction patterns were obtained with an Ultima-IV X-ray diffractometer (Rigaku, Tokyo, J apan). The mineral composition was analyzed according tohe method of Moore \& Reynolds [1], the quantitative composition was estimated with the Rietveld method [2] using the Profex software (Version 3.14.3), [3].

Chemical analysis was determined with X-ray fluorescence spectrometry (XRF) using an Axios mAX XRF spectrometer (PANalytical, Almelo, The Netherlands) at IGEM RAS (Moscow). Samples were dried at $110{ }^{\circ} \mathrm{C}$ and prepared by fusion with lithium borate at $1200{ }^{\circ} \mathrm{C}$. The iron content was determined only as the total $\mathrm{Fe} 2 \mathrm{O} 3$, regardless of the actual valence state of the Fe.

The microstructure of the sorbents was studied with scanning electron microscopy (SEM) using a LEO1450VP SEM (Carl Zeiss, Oberkochen, Germany). Samples for SEM were prepared in the form of individual particles and aggregates.

The specific surface area was determined with a Quadrasorb SI/Kr analyzer (Quantachrome Instruments, Boynton Beach, FL, USA). Adsorption was performed at liquid nitrogen temperature (77.35 K). Microporosity was determined by the T-Method.

Determination of CEC was carried out by two methods [4] - by adsorption of methylene blue (MB) [5] and of $\mathrm{Cu}$ (trien) [6,7].

Technological properties were determined on industrial samples of bentonite powder.

\section{Results and Discussion}

\subsection{Regional geology and geology of the 10th Khutor bentonite deposit}

The deposits in the Republic of Khakassia are localized within the occurrence of the continental tuff-sand-clay argillaceous coal-bearing formation of the Carboniferous age and are located within the Chernogorskiy and Izykhskiy coal areas of the Minusinskiy basin, confined to the AltaiSayanfolded zone (fig. 1) [8]. In addition to the 10th Khutor deposit, the Karatigeyskoe, Solnechnoe, Karasukskoe and Solnechnoe bentonite deposits are confined to the same age range within the basin. The geological structure of the the Minusinskiy basin consists of volcanic, volcano-sedimentary, terrigenous and carboniferous sediments of Devonian and Carboniferous age. The coal-bearing strata of the Middle and Upper Carboniferous age contain large deposits of hard coal. A special geological and genetic type of bentonites, associated with coal-bearing formations, is distinguished [9,10].

The 10th Khutor deposit is located in the northwestern part of the Chernogorsky basin. The bentonite-bearing strata is confined to the lower part of the coal formation. The formation is composed of conglomerates, sandstones, siltstones, mudstones, limestones, carbonaceous rocks with seams and interlayers of hard coals and bentonites. 
In the structure of the tuffaceous-sandy-clayey bentonite-bearing formation of the Carboniferous age, 5 benches containing layers of bentonite are distinguished [11]. The second bench is of industrial importance, confined to Sarskaya suite (C1-2sr) of the Early-Middle Carboniferous strata, with a thickness of $35 \mathrm{~m}$. This bench consists of 6 bentonite layers, interbedded with coal seams and tuffterrigenous material. Bentonite layers have monoclinal bedding with a northeastern course and dip to the southeast at an angle of $6-8^{\circ}$, with a mean thickness from 1.5 to $4 \mathrm{~m}$. The layers are separated by terrigenous and carbonaceous rocks.

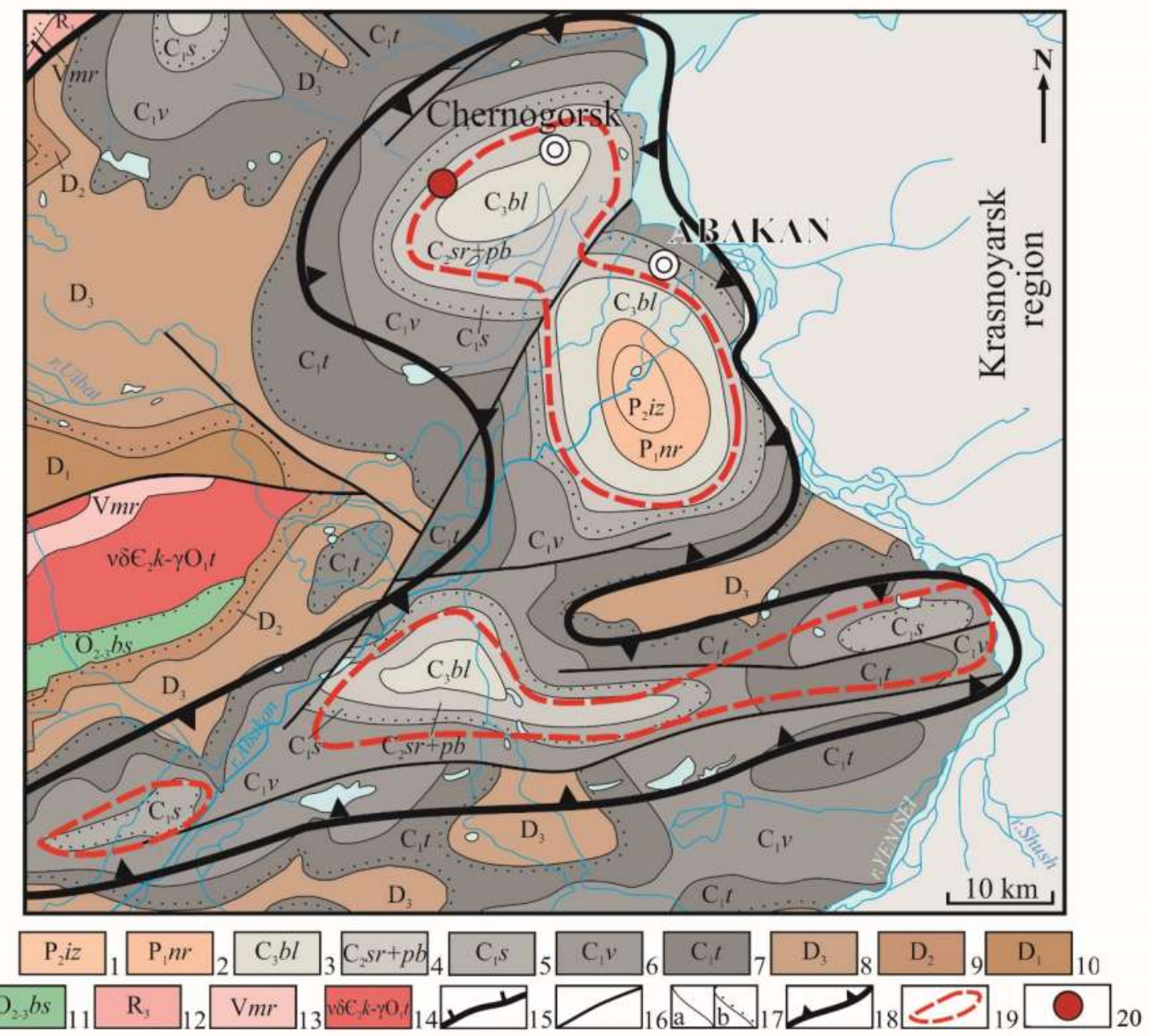

Figure 1. Geological map of the Chernogorsky basin (Strunin, Glukhov, 2002, with edition). Legend: 1-3 - Paleiogene system, Paleocene-Eocene, siltstones, mudstones, sandstones, coal: 1 - Iikh suite; 2 Narylk Formation; 4-7 - Carboniferous system, lower-upper sections (3 - Beloyarskaya suite, sandstones, siltstones, mudstones, coal, 4 - Sarsky, Montenegrin, coastal retinues, siltstones, sandstones, mudstones, limestone, bentonite clay, coal, 5 - the Serpukhov layer, sandstones, conglomerates, siltstones, coal, 6 - the Visean layer, sandstones, conglomerates, siltstones, coal, 7 - the Tournaisian layer, tuff sandstones, limestone, conglomerates); 8-10 - Devonian system (8 - upper section, mudstones, sandstones, marls, 9 - middle section, sandstones, limestone, siltstones, marls, 10 - lower section, sandstones, siltstones, gravelites, basalts); 11 - Ordovician, middle-upper sections (Bolshesyrskaya suite, tuffs, trachyandesites, trachybasalts); 12 - Riphean, upper section (limestone, dolomites, silicites); 13 - Vendian (Martyukhinskaya suite, limestone, dolomites, silicites); 14 - Middle Cambrian-Late Ordovician intrusions (granites, granodiorites, syenites, gabbrodiorites, gabbro, monocytes); 15 - thrusts; 16 - faults; 17 - geological boundaries (a - reliable; b - facies different); 18 - 
borders of the Yuzhno-Minusinsk coal basin; 19 - bentonitiferous and potentially promising areas; 20 - 10th Khutor deposit.

\subsection{Analytical research}

\subsubsection{Structure and texture}

Bentonites are mostly gray, dark gray, less often greenish or bluish gray with a massive texture (fig. 2a) with interlayers of coal or coalified rocks of $0.1-1 \mathrm{~m}$ thick (fig. $2 \mathrm{~b}$ ). The main part of the bentonite mass has a pelitic or silty-pelitic structure with inclusions of individual detrital grains and authigenic minerals up to $0.7 \mathrm{~mm}$ and sometimes with lenses and interlayers of carbonized organic matter. Montmorillonite is represented by flat and wavy smectite flakes ranging in size from 0.5 to $2-$ 3 microns. The clay mass contains meso- and macropores with a diameter of 4 to $7 \mu \mathrm{m}$. Studies of the crystalline fraction, washed from the clay, made it possible to find isomorphic fragments of volcanic glass (fig.2c,d). Transformed feldspar grains, as well as relics of volcanic glass with a porous structure, are observed in the electron microscope images.

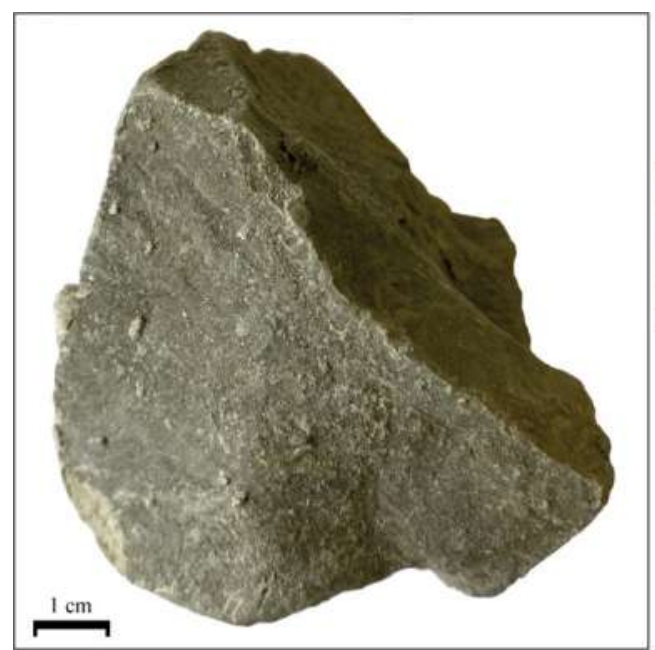

(a)

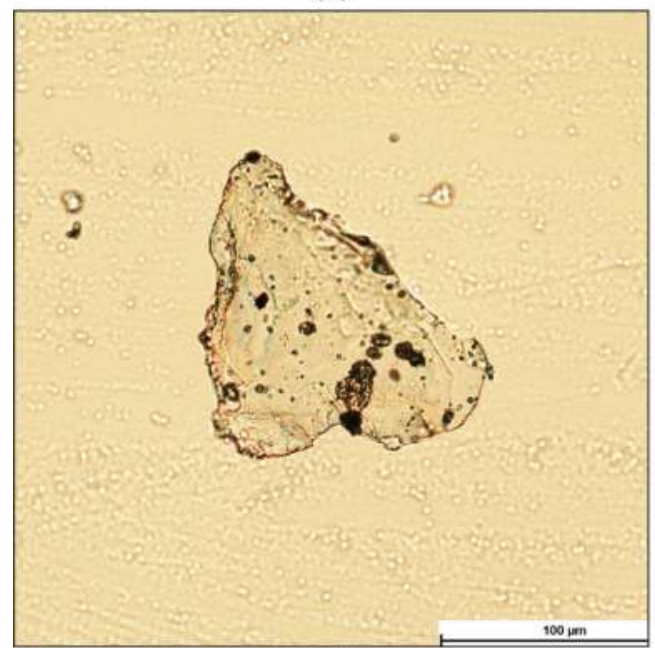

(c)

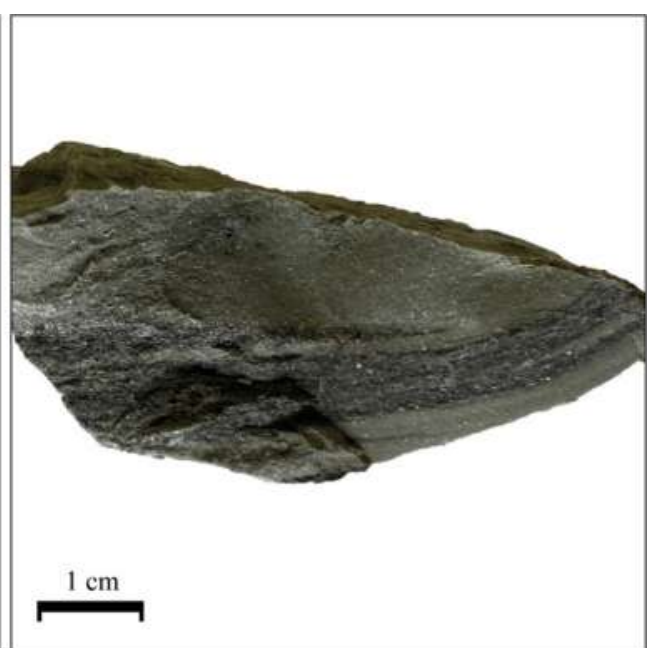

(b)

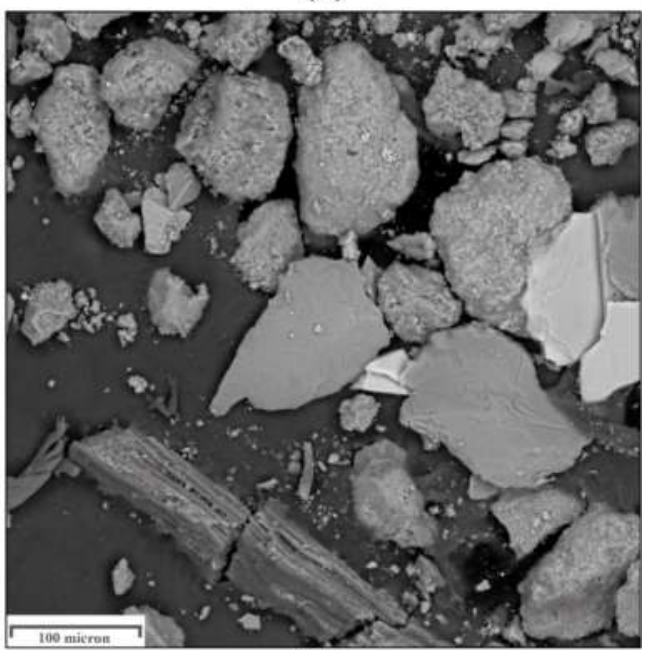

(d)

Figure 2. Macro- and microphotographs of bentonite samples and crystalline fraction: $a$, $b$ - bentonite samples; $c, d$ - relics of volcanic glass.

\subsubsection{Mineral composition}


Bentonites of the 10th Khutor deposit are rocks of predominantly montmorillonite composition with admixture of kaolinite, chlorite, illite, quartz, field spars, calcite and gupsum (table 1). The maximum content of montmorillonite is typical for the IV, V and VI layers and reaches a maximum of $70-75 \%$ with an average content of $63 \%$. In addition to montmorillonite, all beds contain kaolinite (0.7-6.8\%), illite (2-5\%) and chlorite (0.1-6.2\%). Quartz, potassium feldspar and plagioclase are the most widespread among non-clay minerals. Small amounts of gypsum (0-3.1\%), calcite (0-4.6\%), ankerite $(0-1.4 \%$ ) and hematite (average of $0-0.6 \%$, with single samples of up to $3 \%$ ) are present in all layers. At the same time, gypsum crystals in bentonite samples reach rather large sizes - up to $0.5 \mathrm{~cm}$ diameter. Siderite (up to $10-11 \%$ ) is present only in the top of the V and the bottom of the VI layer. Also, there are single grains of jarosite (up to $3 \%$ ) and rutile (up to $0.5 \%$ ).

The purified sample of bentonite (fraction $<1 \mu \mathrm{m}$ ) predominantly consisted of $92.4 \%$ Namontmorillonite [12]. The bulk sample is of alkaline-earth type. Thus, the natural bentonite contains two phases of montmorillonite with different cationic compositions, which possibly traces different stages of bentonite formation or transformation of pore water composition.

Table 1. Mineral composition of the examined samples, $\%$.

\begin{tabular}{|c|c|c|c|c|c|c|c|c|c|c|c|c|c|c|}
\hline$\stackrel{\vec{D}}{\stackrel{\Xi}{త}}$ & 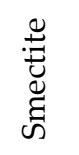 & 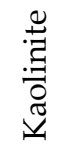 & $\stackrel{\stackrel{ \pm}{*}}{\Xi}$ & 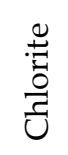 & 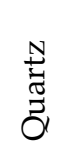 & 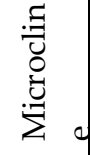 & 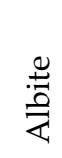 & 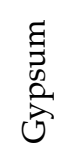 & $\frac{\mathscr{U}}{0}$ & $\frac{0}{ \pm \frac{7}{0}}$ & 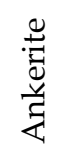 & 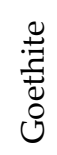 & 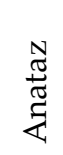 & 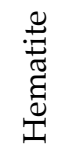 \\
\hline II & 65,5 & 2,9 & 3,7 & 1,4 & 9,8 & 5,5 & 5,7 & 0,4 & 4,6 & 0 & 0,4 & 0 & 0 & 0,1 \\
\hline IV & 72 & 1 & 4,5 & 0,5 & 10,1 & 5,3 & 5,3 & 0 & 1,3 & 0 & 0 & 0 & 0 & 0 \\
\hline V & 63,4 & 3,3 & 3,6 & 0,3 & 13,6 & 6,3 & 7 & 0,3 & 1,3 & 0 & 0,8 & 0 & 0 & 0,1 \\
\hline VI & 70,2 & 1,6 & 2,4 & 1,2 & 12,6 & 5,6 & 4,7 & 0,5 & 1,1 & 0 & 0 & 0 & 0 & 0,1 \\
\hline IB-6 & 72,3 & 0,5 & 3,7 & 0,7 & 12,1 & 4,1 & 4,4 & 0 & 0,7 & 0,7 & 0,8 & 0 & 0,7 & 0 \\
\hline $\begin{array}{l}<1 \\
\mu \mathrm{m}\end{array}$ & 92,4 & 0,5 & 3,7 & 0,7 & 2,0 & 0 & 0 & 0 & 0 & 0 & 0 & 0 & 0,7 & 0 \\
\hline
\end{tabular}

\subsection{Genesis and conditions of formation}

The bentonite occurrence of this area is confined to the Minusinsk coal basin. As is known, the conditions of sedimentation of fossil coals are favorable for the formation of bentonites from pyroclastic material, and at the same time, the composition of trace elements of the studied bentonites is characteristic of igneous rocks [13]. For this reason, a diagenetic model of bentonite formation has been proposed. The original tuff material has not been preserved along the deposit. The ratios of trace elements were used to establish some characteristics of the source rocks [14,15]. The results obtained indicate the rhyodacite and dacite composition of the initial ashes.

The study of paleogeographic maps [16] made it possible to reconstruct the sedimentary environment in the studied region. It was a foredeep with the accumulation of sediments transported from the neighboring mountain structures. The beginning of the accumulation of sediments of the Sarskaya suite was accompanied by the activation of the Western Sayan volcanism. The Minusinsk basin at that time was a shallow water zone with an inland sea, bays and lagoons or a system of interconnected large lakes, forming a single water body of sea-lake type.

\subsection{Properties}

The geological conditions of the formation of bentonites of the 10th Khutor deposit had a strong influence on their properties. After the diagenetic stage, the already formed bentonites were affected by the initial stage of metamorphism, as evidenced by the seams of hard coal. Such conditions led to significant compaction of bentonites, mainly due to the degradation of microporosity, so that the specific surface area is determined only by the presence of meso- and macropores and equal to 13 $\mathrm{m} 2 / \mathrm{g}$ while preserving the ability to swell. 
The testing of technological samples indicates the high quality of sandy-clayey forms based on this bentonite. However, to achieve such quality characteristics, it is necessary to carry out mechanical activation and aging of the bentonite with the addition of soda ash. The swelling index of the original bentonite is $4 \mathrm{ml} / 2 \mathrm{~g}$, however, after activation with soda ash, it increases to $27 \mathrm{ml} / 2 \mathrm{~g}$.

The result of CEC determination by $\mathrm{MB}$ on natural sample ranges from $23-27 \mathrm{cmol} . \mathrm{kg}-1$ for samples from layer II and 54-63 cmol.kg-1 for samples from layers IV, V and VI. The CEC values measured with the copper complex showed higher values, namely $31-35 \mathrm{cmol} . \mathrm{kg}-1$ for layer II and 50-80 cmol.kg-1 for samples from layers IV, V and VI.

\section{Conclusions}

The 10th Khutor bentonite deposit, located in the Republic of Khakassia (Russia) within the development of continental tuff-sandy-argillaceous formation of the Chernogorsky basin which is confined to the Early-Middle Carboniferous sediments of the Sarskaya suite (C1-2sr). The bench consists of 6 layers of bentonite, interbedded with coal seams and tuff-terrigenous material. An average content of montmorillonite is $55-70 \%$. It was found that sample of raw bentonite belongs to the alkaline-earth type, while purified sample with fraction $<1 \mu \mathrm{m}$ corresponds to sodium montmorillonite.

The trace element composition of bentonites, as well as the presence of relics of volcanic glass and feldspar with a porous and layered structure, indicate that these bentonites belong to the diagenetic type with rhyodacite and dacite composition of the initial ashes.

The study of paleogeographic maps, as well as the peculiarities of the mineral composition, suggest that the accumulation of tuff material took place in the zone of shallow sea water - bays and lagoons or in the system of interconnected lakes. The influence of metamorphism, as evidenced by seams and packs of hard coal, affected the textural and surface properties of bentonites resulting in the absence of microporosity, a low specific surface area and low moisture content in the raw materials.

Author Contributions: Petr Belousov: geological exploration, preparation of the material, and wrote the Paper; Nikita Chupalenkov, Victoria Krupskaya, Olga Dorzhieva: geological exploration, preparation of the material; George Christidis: analysis and preparation of the material, wrote the Paper, Sergey Zakusin, Ivan Morozov: carried out X-ray diffraction analysis; Mikhail Chernov: carried out SEM pictures.

Funding and Acknowledgments: This work was financially supported by the Russian Science Foundation (project No. 16-17-10270). The authors also express their gratitude to the "Bentonit Company" and "Bentonite of Khakassia" companies for the provided materials and the opportunity to conduct field work at the 10th Khutor deposit.

Conflicts of Interest: Declare conflicts of interest or state "The authors declare no conflict of interest." Authors must identify and declare any personal circumstances or interest that may be perceived as inappropriately influencing the representation or interpretation of reported research results. Any role of the funders in the design of the study; in the collection, analyses or interpretation of data; in the writing of the manuscript, or in the decision to publish the results must be declared in this section. If there is no role, please state "The funders had no role in the design of the study; in the collection, analyses, or interpretation of data; in the writing of the manuscript, or in the decision to publish the results".

\section{References}

1. Moore, D.M.; Reynolds, R.C.J r. X-ray Diffraction and thædentification and Analysis of Clay Minerals, 2nd ed. Oxford University Press, 1999, Oxford, UK; New York, pp. 378.

2. Post, J .E.; Bish, D.L. Rietveld refinement of crystal structures using powder X-ray diffraction data. Rev. Miner. Geochem 1989, Volume20, pp. 277-308.

3. Doebelin, N.; Kleeberg, R. Profex: A graphical user interface for the Rietveld refinement program BGMN. J . Appl. Cryst 2015, 48, pp. 15731580 
4. Belousov, P.E.; Pokidko, B.V.; Zakusin, S.V.; Krupskaya, V.V. Quantitative methods for quantification of montmorillonite content in bentonite clays. Georesursy 2020, 22(3), pp. 38-47. DOI: https://doi.org/10.18599/grs.2020.3.38-47

5. Kaufhold, S.; Dohrmann, R.; Ufer, K.; Meyer F.M. Comparison of methods for the quantification of montmorillonite in bentonites. Applied Clay Science 2002, 22, pp. 145-151. https://doi.org/10.1016/S01691317(02)00131-X

6. Lorenz, P.; Meier, L.; Kahr, G. Determination of the cation exchange capacity (CEC) of clay minerals using the complexes of copper (II) ion with triethylenetetramine and tetraethylenepentamine. Clays Clay Miner. 1999, 47, pp. 386-388.

7. Dohrmann, R.; Genske, D.; Karnland, O.; Kaufhold, S. Interlaboratory CEC and exchangeable cation study of bentonite buffer materials: I. Cu(II)-triethylenetetramine mthod. Clays and Clay Minerals 2012, 60(2), pp. 162-175. https://doi.org/10.1346/CCMN.2012.0600206

8. Belousov, P.E.; Krupskaya, V.V. Bentonite clays of Russia and neighboring countries. Georesursy 2019, 21(3), pp. 79-90 DOI: https://doi.org/10.18599/grs.2019.3.79-90

9. Belousov, P.E.; Krupskaya, V.V.; Zakusin, S.V.; Zhigarev, V.V. Bentonite clays from 10th Khutor deposite: features of genesis, composition and adsorption properties. RUDN J ournal of Engineering Researches 2017, 18(1), pp. 135-143. (In Russ.) https://doi.org/10.22363/2312-8143-2017-18-1-135-143

10. Belousov, P.E.; Krupskaya, V.V. Bentonite clays of Russia and neighboring countries. Georesursy 2019, 21(3), pp. 79-90

DOI: https://doi.org/10.18599/grs.2019.3.79-90

11. Sabitov, A.A.; Ruselik, E.S.; Trofimova, F.A.; Teterin, A.N. Russian bentonite: the current state and resource base development potential. Mineral resources of Russia. Economics and Management 2010, 5, pp. 8-17. (In Russ.)

12. Belousov, P.; Semenkova, A.; Egorova, T.; Romanchuk, A.; Zakusin, S.; Dorzhieva, O.; Tyupina, E.; Izosimova, Y.; Tolpeshta, I.; Chernov, M.; Krupskaya, V. Cesium Sorption and Desorption on Glauconite, Bentonite, Zeolite, and Diatomite. Minerals 2019, 9, p.625. https://doi.org/10.3390/min9100625

13. Dai, S.; Ward, C.R.; Graham, I.T.; French D.; Hower, J .C.; Zhao, L.; Wang, X. Altered volcanic ashes in coal and coal-bearing sequences: A review of their nature and significance. Earth-Science Reviews 2017, 175, pp. 44-74.

14. Winchester, J .A.; Floyd, P.A.; Geochemical discrimination of different magma series and their differentiation products using immobile elements. Chem. Geol. 1977, 20, pp. 325-343. https://doi.org/10.1016/0009-2541(77)90057-2

15. Huff, W.D.; Merriman, R.J .; Morgan, D.J .; Roberts, B.; Distribution and tectonic setting of Ordovician K bentonites in the United Kingdom. Geol. Mag. 1993, 130, pp. 93-100 https://doi.org/10.1017/S001675680002375X.

16. Pozner, V.V. Atlas of lithological-paleogeographical map of the USSR. V. II. 1969 (In Russ.)

(C) 2020 by the authors. Submitted for possible open access publication under the terms and conditions of the Creative Commons Attribution (CC BY) license (http://creativecommons.org/licenses/by/4.0/). 